\title{
Reincarnation and personal identity in the lives of Tibetan masters: linking the revelations of three lamas of the Dudjom tradition
}

\author{
Cathy Cantwell ${ }^{\mathrm{a}}$.
}

${ }^{a}$ University of Oxford, United Kingdom, and Ruhr-Universität Bochum, Germany

*catherine.cantwell@wolfson.ox.ac.uk

Cathy Cantwell was a Research Officer at the Faculty of Oriental Studies, University of Oxford, 2002-2015, and is currently involved in a major research project (2017-2019) at the RuhrUniversität Bochum. She specialises in Tibetan and Himalayan tantric rituals of all periods from the $10^{\text {th }}$ century CE. Her publications include, A Noble Noose of Methods, the Lotus Garland Synopsis: A Mahāyoga Tantra and its Commentary" (Vienna 2012, with Robert Mayer). 


\title{
Reincarnation and personal identity in the lives of Tibetan masters: linking the revelations of three lamas of the Dudjom tradition
}

\author{
This paper explores Tibetan understandings of character, personal identity, and \\ questions of authorship, when the life story and spiritual writings involve persons \\ linked by a line of incarnation. The focus is the $20^{\text {th }}$-century Dudjom Rinpoche \\ (bDud 'joms 'jigs bral ye shes rdo rje, 1904-1987), his immediate predecessor, \\ Dudjom Lingpa (bDud 'joms gling pa, 1835-1904), along with a $17^{\text {th }}$-century \\ lama, Düdül Dorje (bDud 'dul rdo rje, 1615-1672). While Tibetan accounts of \\ reincarnating lamas sometimes emphasise continuities, stories of the two \\ Dudjoms make no secret of the contrast between them in terms of their characters \\ and behaviour. Dudjom Rinpoche's main textual work is his important \\ contributions to the Nying ma literature of previous generations. It is clear that \\ the identification between these three lamas gave Dudjom Rinpoche a specific \\ responsibility in this case.
}

Keywords: Tibetan Buddhist Revelations; rebirth and identity; Dudjom; authorship

It is well-known that in Asian Buddhist contexts, the person of the Buddha or other great spiritual master is understood not only in relation to his specific life but also in relation to his previous births, which provide much of the background to his particular spiritual trajectory and the path he takes in the present. Even with ordinary folk, although they may lack the ability to recall their past lives, the assumption is nonetheless that their past lives explain much about their current propensities and about the opportunities they may encounter in this life. In the spiritual path, prior auspicious connections with particular spiritual masters or experience with particular meditative techniques can explain why a person may relate easily with a particular lama or master a spiritual practice effortlessly. Equally, inauspicious connections in the past can explain why others may devote considerable efforts to the spiritual path yet gain no obvious results. 
In the Tibetan case, the notion of a lama as nantrül (rnam 'phrul) or trülpa (sprul pa, 'emanation') of a particular deity or as trülku (sprul sku, 'rebirth') of an earlier great lama may help to inform our appreciation of the individual's character, activities and his entire life-story. Accounts demonstrating the expected qualities in the current lama, or the continuity of his spiritual gifts across his lives are ubiquitous in Tibetan accounts. Indeed, although perhaps rarely recorded in written accounts, those expressing scepticism about the identification of a specific trülku will generally do so by comparing unfavourably the current incumbent's character and qualities with those of the previous lama. The question here is how we make sense of the development of stories about a lama in relation to his recognised previous incarnations, looking both at his own self-identity and at the accounts created about him, as well as considering what kind of impacts this story or stories may have on his written productions. There are doubtless many instances where matters are straightforward: the lama appears almost like a clone of the previous master, displays all the anticipated qualities and appears to take up his predecessor's work with zest. Yet, as stories of the $6^{\text {th }}$ Dalai Lama illustrate (Wickham-Smith 2012; Namgyal Tantric College 2008-2018), ${ }^{1}$ apparent discontinuities in the character and behaviour of a recognised rebirth of a famous lama neither invariably nor exclusively provoke scepticism.

My focus here is a renowned $20^{\text {th }}$-century lama, Dudjom Rinpoche (bDud 'joms 'jigs bral ye shes rdo rje, 1904-1987), who is still personally remembered by many of the current generation of Nyingma lamas (Yeshe Thaye 1999; Shenpen Dawa Rinpoche 1991). The memories of his immediate predecessor, Dudjom Lingpa (bDud 'joms gling pa, 1835-1904, see Holly Gayley 2010 and Ron Garry 2007), remain vivid not only in written sources, but in the stories passed through two or three generations of his students. His heritage moreover lives on in two rather distinct groups: firstly, the 
students and associates of the later Dudjom Rinpoche, and secondly, the inheritors of the tradition who remained in his home area of Amdo, including his family line of sons and grandsons, who became eminent lamas in their own right. In fact, two of the grandsons were also recognised as rebirths of their grandfather. ${ }^{2}$ Since the teachers springing from Dudjom Lingpa's family mostly remained in Tibet, there has been less integration between them and Dudjom Rinpoche's students than might otherwise have been the case, but there have been some overlaps, such as in the case of Chatral Rinpoche (Bya bral sangs rgyas rdo rje 1913-2015, see Yeshe Thaye [n.d.]), who was a student of Sera Khandro (Se ra mkha' 'gro), the consort of one of Dudjom Lingpa's sons, and who also received transmissions from another of Dudjom Lingpa's sons. It may be that as close links are re-invigorated between the lamas who remained in Tibet and those based in India and the Himalayan areas, further exchanges and greater integration will occur. In any case, both groups remain active and the case study materials are thus still accessible today. What is quite clear for the purposes of this article is that we have a rather stark contrast between Dudjom Lingpa and Dudjom Rinpoche, in terms of their characters, behaviour, and their textual productions.

Dudjom Lingpa was said to have been fierce, frightening and unpredictable. His usual title is trantung (khrag 'thung), literally meaning 'blood-drinker' in Tibetan, an equivalent for Sanskrit heruka, which refers to a wrathful tantric deity form. He spent much of his life wandering through the nomadic areas of his homeland of Golok (mGo $\log$ ) in Amdo (in the south-east of contemporary Qinghai), undertaking meditative retreats and experiencing visions which guided his life. He revealed a large new tantric ritual corpus and gradually established his reputation as an enlightened master. He faced considerable obstacles, since he was a self-made lama and not part of any clear monastic hierarchy. Although he had human teachers, the most significant transmissions 
he received apparently came through his visionary encounters, both with the great spiritual figures of the past, and with buddhas and tantric deities. He received visionary confirmation of his status as a rebirth of the earlier renowned figures of Drokben Khyeuchung Lotsāwa ('Brog ban Khye'u chung lo tsā ba), who features in the mythological accounts of Guru Pema (Gu ru Padma), and Düdül Dorje (bDud 'dul rdo rje, 1615-1672), but there was no formal recognition by religious authorities in the area, and it seems that not everyone accepted that he was genuine (see, for example, Dudjom Lingpa [2011, 84-85]). Moreover, he was a rather unconventional holy man, even by Tibetan standards. He was said to have been wild and uncontrollable as a boy. His parents could not manage him and handed him onto a maternal uncle at age ten. Disgruntled by domestic tasks, he caused havoc, and his uncle and aunt despaired of him, concluding that he was possessed by a mischievous the'u rang spirit. They resolved that he should receive a religious training, which would tame his violent tendencies, for as a layman he would inevitably cause immense harm to himself and others. ${ }^{3}$ The version in Dudjom Lingpa's autobiography is slightly less stark, implying that it was Dudjom Lingpa himself who had asked to move from his reluctant parents' house following an indication in a dream. Yet the story about the trouble he caused his uncle and aunt, and their idea that he had been possessed by a the'u rang spirit, is included, and it is clear that this is the source of the account repeated in the later works. ${ }^{4}$ Once Dudjom Lingpa had established himself as a lama, by his own account, his curses were effective and much to be feared (see, for example, Dudjom Lingpa [2004, vol. Dza, 111-112], [2011, 85]), and there is a story that he blessed visitors using his large sword, sometimes beating hard to dispel evil spirits (P. Ogyan Tanzin, personal communication). Many people were said to have been too frightened to go to him for blessings or teachings. 
In contrast, Dudjom Rinpoche was at a young age identified as Dudjom Lingpa's rebirth, became famed as Guru Rinpoche's Regent for the current time, ${ }^{5}$ and he was widely respected as an important lama throughout his life, receiving transmissions and teachings not only from Dudjom Lingpa's students, but also from many of the foremost Nyingma lamas. He received acclaim from lamas of different religious orders, while the widely venerated Rime (ris med) lama, Jamyang Khyentse Chökyi Lodrö ('Jam dbyangs mkhyen brtse chos kyi blo gros, 1893-1959), was said to have announced that he was an emanation of Guru Rinpoche himself. ${ }^{6}$ This apparently encouraged many Sakya students of the great master to make a connection with Dudjom Rinpoche. Dudjom Rinpoche's training encompassed the whole Nyingma textual and ritual practice heritage, and he became especially identified with the Central Tibetan monastery of Mindröling (sMin grol gling), whose famous $17-18^{\text {th }}$-century lamas had done much to promote and integrate the wider Nyingma tradition throughout Tibet. He became a prolific scholar, spending much of his life teaching and writing. He produced a number of his own revelations, but he is especially famed for his extensive editorial and commentarial work on the revelations of previous generations. ${ }^{7}$ Dudjom Rinpoche acted as a central figure in the collective task of preserving the Nyingma heritage in its time of crisis following the Chinese invasion of Tibet. He became the first Head of the Nyingma tradition, when a formal modern structure was created in exile. Unlike his predecessor, he spent little time in retreat. It is generally said that this was because he mastered the teachings in his previous lives. It is assumed that even a lama identified as a former master reborn must nonetheless again receive transmissions in his new life and complete the practice requirements. Dudjom Rinpoche did this, but it is said that since he retained the qualities of the enlightened mind continua of his former lives, the attainments came naturally, merely on hearing the teachings. ${ }^{8}$ He himself, at least in 
writing, instead emphasised the transmissions of his root lamas. He related that following the direct introduction to the nature of mind bestowed upon him by Zilnön Namkhe Dorje (Zil gnon Nam mkha'i rdo rje), spiritual understanding came easily, and he had no need to endure the hardships of long retreats. ${ }^{9}$

In his character, Dudjom Rinpoche was mild, patient, and gracious. There are stories of how his first wife left him, taking with her virtually all the family property, with his ready acquiescence. The story goes that the local people were so shocked and astonished by the situation, that they flocked to the house the following day, refurnishing it within a short space of time. ${ }^{10}$ Since he was apparently unable to refuse requests or turn anyone away, as his fame grew, his second wife had to take on the job of guard, protecting him from a constant barrage of visitors. Some accounts suggest that Dudjom Rinpoche did have a "wrathful" side, which would come out occasionally, especially when he was younger. One such remembered incident was his anger when his horses became distressed, after a stablehand had failed to allow them to graze while travelling. ${ }^{11}$ Yet even stories of this kind, which may in any case draw attention to other positive features of Dudjom Rinpoche's character, such as his compassion towards the animals, would seem to underline the idea that this aspect of Dudjom Rinpoche's personality was mostly kept under tight control.

I must stress that the brief characterisation here of contrasts in the most usual portrayals of the two lamas does not attempt a complete or nuanced account. My knowledge is limited, and I do not to wish to imply that these depictions accurately and fully reflect the actual realities. This article is not seeking to represent the truth about the lamas, nor even to create a balanced account based on all available accounts. Rather, it is considering popular stories which Tibetans re-tell about their lamas, and how they make sense of such disparities in the case of stories concerning reincarnations. The 
main point is that here, attention is drawn to one lama's fearsome demeanour and behaviour, as well as his specific style of visionary accomplishments and literary compositions, while his reincarnation is lauded for quite contrasting personal characteristics and styles of practice, writing, and teaching.

Perhaps most remarkable is Dudjom Rinpoche's own self-identification with Dudjom Lingpa. He had been a young child when he was first recognised as Dudjom Lingpa's rebirth, and it might be supposed that he had simply accepted the situation. Yet on the contrary, not only was he actively involved in self-identifying with Dudjom Lingpa as a boy, but he continued to do so throughout his life. ${ }^{12}$ Above all, his commitment to Dudjom Lingpa's spiritual legacy is beyond doubt: he invested considerable time and energy in working and teaching on Dudjom Lingpa's corpus. It is also noteworthy that far from glossing over the apparent unsavoury aspects of Dudjom Lingpa's character, the tradition has retold the stories of Dudjom Lingpa's escapades as a boy, and this includes Dudjom Rinpoche's own writings about his predecessor. Indeed, the story is recounted in Dudjom Rinpoche's introductory logyü (lo rgyus, 'historical account') to his two-volume re-presentation of Dudjom Lingpa's famous revelation focussing on the tantric deity, Vajrakīlaya (vol. Tha, 63-64). Such an historical account is not intended as a dry scholarly recital of facts. The principal intended context for its reading is where a lama is introducing a group of retreatants to the practice, before they embark on intensive meditation. Thus, the story is integrated into a highly charged symbolic presentation, emphasising the daknang (dag snang, 'pure vision') of the enlightened teacher and the enlightening teaching which the students have had the great good fortune to encounter. So Dudjom Lingpa's character is celebrated in Dudjom Rinpoche's own religious presentation of the tradition. 
To understand our Tibetan sources' linkage of such apparently different lamas, we must consider what is meant by the rebirth of a series of lamas. From one approach which is a significant part of Tibetan tradition, the lama is quite simply the same individual, whose stream of consciousness continues from life to life, incorporating the memories, propensities, and enlightened vision of his previous births. But often, the emphasis is on the continuity of the enlightened vision or mind, rather than all the aggregates of the previous personality. One of the saints of the past with whom the Dudjom lamas are identified is the Indian tantric master, Hūmkara. ${ }^{13}$ An incident in Dudjom Lingpa's visionary autobiography has Hūṃkara appearing to him to provide spiritual encouragement. Dudjom Lingpa bemoans his failure and appeals to Hūṃkara for help. Hūṃkara then bestows teachings and finally promises: "My enlightened vision will shift to your mindstream - the sacred pith instructions will overflow like a river", at which Dudjom Lingpa awakened within the dream. ${ }^{14}$ There is not here such explicit identification between the two in the same way that Dudjom Lingpa repeatedly presents himself as a self-aware rebirth of Khyeuchung and Düdül Dorje throughout the autobiographies, ${ }^{15}$ yet this story can be understood in the light of the inclusion of Hūṃkara in the line of his previous emanations, which is clearly stated at the beginning both of this autobiography and the shorter "secret" autobiography which follows in his Collected Works. ${ }^{16}$ Hūmpkara continues to appear to Dudjom Lingpa on various occasions recorded in the account, and in one later episode, he advises Dudjom Lingpa that he is his activity emanation. ${ }^{17}$ Perhaps a more explicit focus on the enlightened vision as the key component in linking the reborn lama with his predecessors comes from one account of Dudjom Rinpoche's early relationship with Puktrül Gyurme Ngedön Wangpo (Phug sprul 'Gyur med nges don dbang po), a student of Dudjom Lingpa who became one of his root lamas. Gyurme Ngedön Wangpo is cited as 
affirming Dudjom Rinpoche's identification with Dudjom Lingpa, specifically saying that although he had exchanged an old for a young body, his undiminished enlightened vision was unchanged. ${ }^{18}$ In similar vein, in relation to Dudjom Rinpoche's lives, Khenpo Tsewang Dongyal comments that the enlightened qualities of his visions and realisations were not discarded along with the aggregates (Tib. phung po, Skt. skandha) of each of the bodies in his series of rebirths, like a snake changing its skin. This would seem to suggest that personal characteristics of each lama, which would be part of their aggregates, are discarded at the end of that particular life, yet the visionary realisation endures. $^{19}$

A common Tibetan analogy applied to a series of reincarnating lamas is that of a string of pearls. This image is given in the title of the supplication to the Dudjom incarnation line, entitled The Supplication to the Series of Rebirths, the Pearl Necklace (Skyes rabs gsol 'debs muktika'i do shal [Dudjom Rinpoche 1979-1985, vol. A, 2531]) and the Düdül Dorje supplication collection uses the same image ("a garland of pearls", mu tig phreng ba, from Sanskrit muktikā [Düdül Dorje 1997, vol. Tha, 233]). Each pearl consists wholly of the same precious material, is connected to the previous and subsequent pearl in the string, and together the pearls form a beautiful adornment. Yet each is a distinct and individual pearl, and not in any sense a literal part of a single item. Perhaps one limitation to the pearl analogy is that although it works if the pearllike quality is considered to refer specifically to the enlightened qualities (and this is surely intended in its traditional context of poetic supplications to the line of lamas), the similarity in the substance of the pearls may take the focus away from the differences between the individuals. Yet as we have seen, these differences may be celebrated.

The forcefulness of the idea of a simplistic movement of a single person from life to life may be slightly undermined by the idea that the enlightened person needs to 
adapt their manifestation to the circumstances in order to be effective. The greater the enlightened person, the more likely they are to master and display many different kinds of appearances for the benefit of different individuals. The greatness of the Dudjom lamas is expressed in the supplications to the series of rebirths, starting with a vidyādhara of a past age and concluding with a buddha of a future aeon (see the short version of the supplication, vol. A, 31).

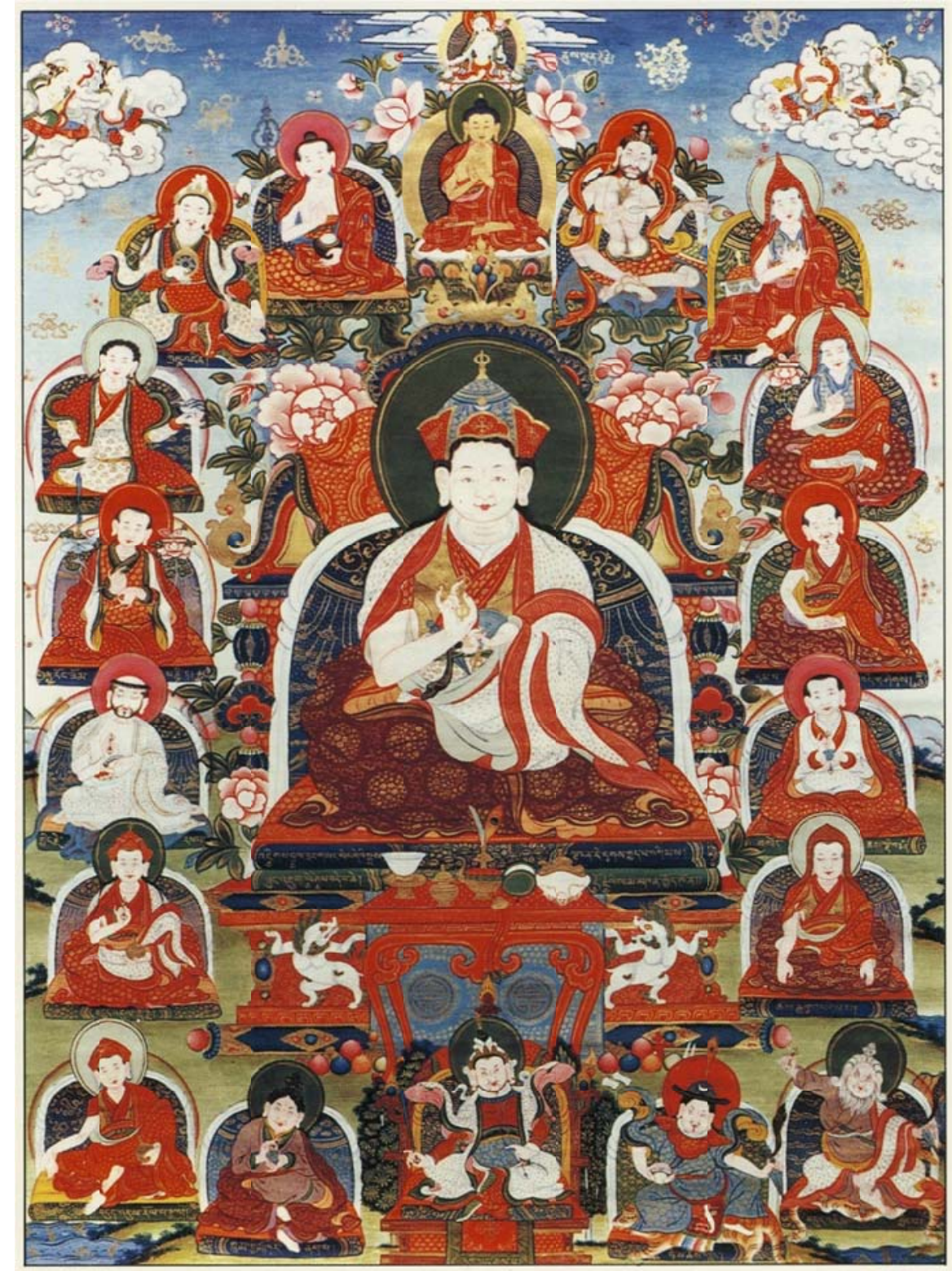

Figure 1. Dudjom Rinpoche and his series of rebirth (online, URL:

http://Dudjominternational.org/wp-content/uploads/2015/08/HH-Dudjom-RinpochesLegendary-Incarnations-small.jpg). 


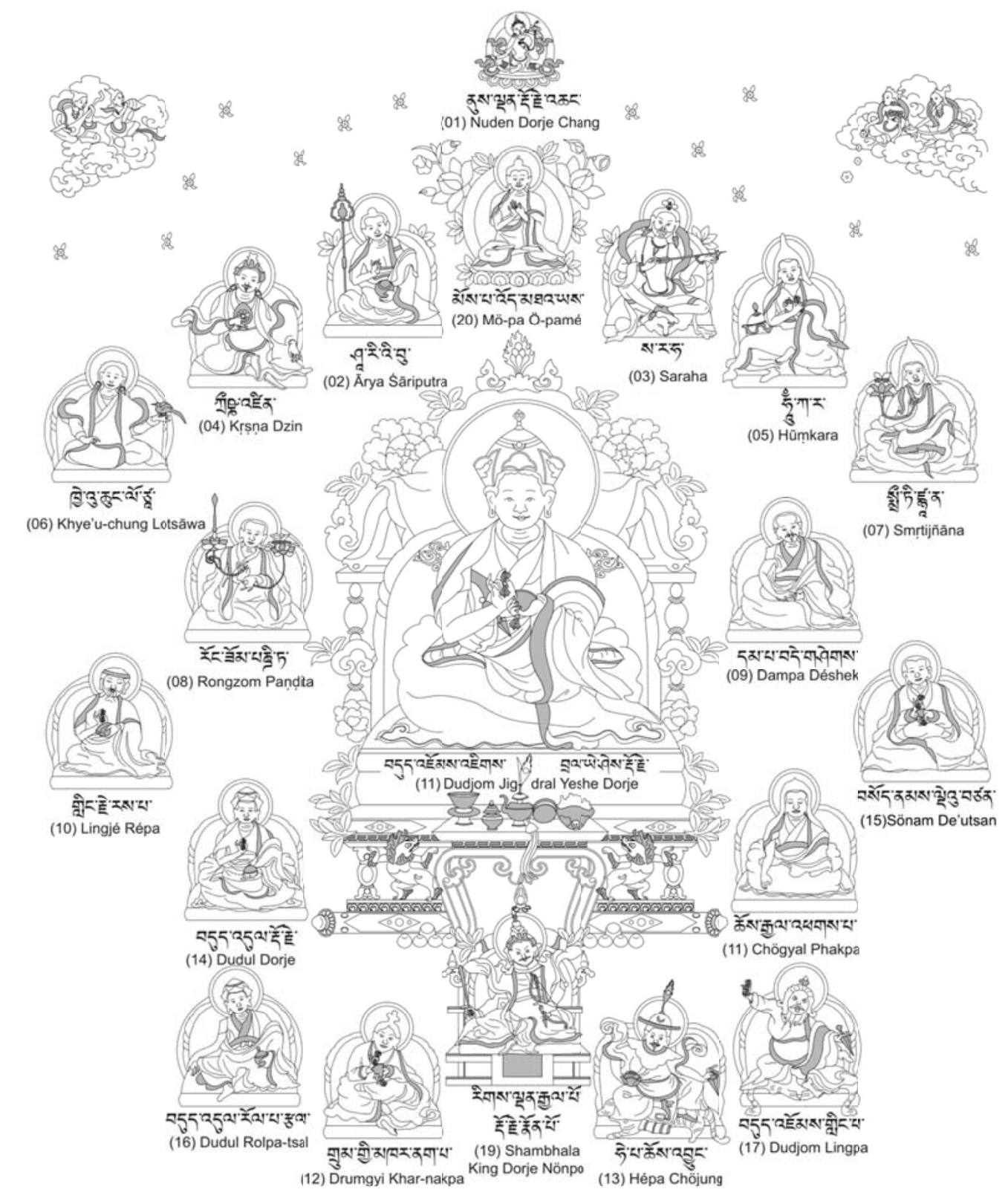

Figure 2. Key to Dudjom Rinpoche's series of Rebirths. Image by Vasso Mamali and Cathy Cantwell. 
The image above is that of a multi-fold display of enlightened manifestations, varying according to the context or field of beings to be tamed. In the case of the Dudjom lamas, the differences between Dudjom Lingpa and his later incarnation are often linked to their differing environments. Dudjom Lingpa lived in an area which lacked centralised authorities, where personal strength and bravado was a necessary quality for a successful male adult, and where feuding groups often appealed to lamas to adjudicate their disputes. Moreover, he operated in a spiritually competitive environment in which many would-be lamas were seeking to establish their spiritual worth. Under these circumstances, he needed to assert magisterial strength and dignity, and he is said to have appeared like a ruler in a court, armed with his sword..$^{20}$ In contrast, Dudjom Rinpoche was born in an area of Pemako where the people are considered somewhat self-effacing by Eastern Tibetan standards. Dudjom Rinpoche had no need to struggle or impress anyone with a show of strength. His reputation as a lama developed naturally, and his mild-mannered unassuming character and studious dedication to all the riches of teachings placed before him was more appropriate to his circumstances. ${ }^{21}$

This principle of adjusting the personal presentation in accordance with the outer circumstances is clearly an important strand in Tibetan understandings of the differences among a line of reincarnating lamas, but it may not be in itself quite adequate to account for the extent of the contrast between the two Dudjom lamas. It seems that some notion of a real personal change and a progression over a number of lives is not ruled out, even if it is not explicit that there is any spiritual development from the already perfected saint of the past. The analogy of a river may be used, a common enough image in the Buddhist context of the transmigrating stream of consciousness. As Lopon P. Ogyan Tanzin put it, the River Ganges may look the same at any particular place, and in some sense remains the same Mother Gangā, yet the river 
continuously flows onward, and its components change. Moreover, a river appears quite different at its source and at its mouth as it broadens to meet the sea. Thus:

Dudjom Lingpa and Dudjom Rinpoche [...] [are] different person[s]. They are different in time and place. They are different in style of work. Of [...] [course,] they are [the] same in spirit and qualities [...] forever, Gangā will be the same. (Personal communication, March 2006)

There is a further idea that just as an individual in a single life may grow and develop in unexpected ways, so a lama may change rather dramatically from one life to the next. Another simile suggested by Lopon P. Ogyan Tanzin is that of a baby bird, growing within its nest. In this case, the nesting materials were Dudjom Rinpoche's cultural environment in Pemako, while the parental nourishment took the form of his early teachers, especially Dudjom Lingpa's students, and these were both formative influences on his character. Yet in time, the bird outgrows the nest and may fly off into new territories. Dudjom Rinpoche's involvement with the Mindröling lamas could be seen as the equivalent of his college education, and it was this later influence which he then developed much in his maturity. However, it may be that this simile rather understates the breadth of the education which Dudjom Rinpoche already received from childhood. His principal root lama for the Dudjom lineage transmissions, Gyurme Ngedön Wangpo (see above), also bestowed upon him Kongtrül (Kong sprul)'s Treasury of Revelations (Rin chen gter mdzod), the Khyentse (mKhyen brtse) cycles, Longchenpa (Klong chen pa)'s works, as well as the Mindröling tradition revelations and Terdak Lingpa (gTer bdag gling pa)'s collection of older revelation practices (sgrub thabs 'dod 'jo bum bzang). ${ }^{22}$ So it would appear that Dudjom Rinpoche's own emphasis on a broader field than his predecessor not only reflects the development of his own character and abilities, but also fulfilled the wishes of his earliest teachers, ${ }^{23}$ not to mention the prophecy cited above, which also highlights the potential for involvement 
in the older revelations (see note 7). It is not hard to account for the new directions of his work in terms of the principle of fulfilling the needs of beings. With his erudite scholarship and well-composed writings, he brought Dudjom Lingpa's sometimes slightly idiosyncratic revelations into the mainstream, universalising a rather specific Eastern Tibetan lineage with its reference to the traditions of Katok (Kah thog) lamas and the heritage of the Eastern Revelations (shar gter). He drew on the kama (bka' $m a)$ or transmitted corpus of tantras and commentarial works to enrich his presentations of Dudjom Lingpa's revelations, as well as broadening his own expertise to encompass the revelations of the other Nyingma lineages.

There is one more Tibetan - and more broadly, Asian Buddhist —idea which is a significant part of the stories of Dudjom Lingpa's change of form into Dudjom Rinpoche, and that is the force of aspirations. It is not simply that an enlightened person passively responds to circumstances, and manifests somewhat mechanically in a new manner. Rather, they understand the needs of the future, and make a positive aspiration to appear appropriately. There is one delightful story which I have not seen in any written source, but which seems well-established as an oral tradition amongst followers of the Dudjom tradition. The story goes that at the end of his life, Dudjom Lingpa reflected on the fact that his scary appearance and troublesome character had frightened some followers away and even caused difficulties to his more committed students. In kindness to them, he then made a firm promise that he would return in a particularly peaceful and gentle form. In one version, it was one of his consorts who first made a request that he should do so, and he willingly accepted the request. Thus, as a result (and this final part of the story is written down), Dudjom Rinpoche was destined to become a person endowed with wisdom yet with whimsical childlike behaviour. ${ }^{24}$ 
There is also the idea that a reincarnate lama should imbue their spiritual practice with aspirations connected to their previous births. Dzongsar Khyentse Rinpoche (rDzong gsar mKhyen brtse, b. 1961) recounts how he was advised by his teacher, Dilgo Khyentse (Dil mgo mkhyen brtse, 1910-1991), that whenever he doubted his own identity, he should pray to his predecessors, Jamyang Khyentse Wangpo ('Jam dbyangs mkhyen brtse dbang po, 1820-1892) and Jamyang Khyentse Chökyi Lodrö (1893-1959), praying that he would fulfil their aspirations (Dzongsar Khyentse Rinpoche 2018).

It is the notion of the power of aspirations which is central to understanding the Nyingma system of revelation and the specific associations between each revealer and his place in the mythological accounts of Guru Rinpoche's establishment of the tantric teachings in Tibet. Each revealer is seen as an emanation of one of Guru Rinpoche's first students in Tibet, who not only mastered the specific meditative systems they would later reveal, but who were each allotted a specific share of the instructions (gdams skal) and who then accepted the charge (gnyer gtad) from the Great Guru to recover and to propagate these teachings at a later specific time. Thus, they are reborn through the force of their earlier aspirations. ${ }^{25}$

Although the theory clearly links the different rebirths as all emanations of the one original enlightened student, the notion of the timeliness of each recovery implies that we should expect some variations in the line of lamas. It is possible that a lama might reveal further texts of the same cycle as his predecessor, but more likely that he will have a new role more appropriate for his time, possibly to develop the teachings further, or to open a new set from his originally allotted instructions. Dudjom Rinpoche did both of these. His Vajrakīlaya revelation (the Razor Disintegration-on-touch, spu gri reg phung) is quite different from the Vajrakīlaya revelations of Dudjom Lingpa, on 
which he also worked. In fact, his two volume Meteoric Iron Razor (Gnam lcags spu gri) is primarily a re-presentation of Dudjom Lingpa's Sealed Secret Heart Practice (Thugs sgrub gsang ba'i rgya can), but it integrates aspects of the earlier Düdül Dorje's Vajrakilaya revelation, as well as expanding the key recitations with reference to the transmitted literature and including further teachings from the broader Vajrakīlaya tradition.

It is clear that an important element in a revealer's identity will be that of the Guru Rinpoche student they are thought to embody, and in the Dudjom case, this is Drokben Khyeuchung Lotsāwa (Mandelbaum 2007). He is especially connected with wrathful deity practice. In many depictions, he is shown holding or seated beside a bird. This is associated with his successful accomplishment of the Vajrakīlaya practice, when he demonstrated the miraculous ability to summon birds from the sky simply by looking and making the pointing forefinger gesture. ${ }^{26} \mathrm{He}$ is also considered to be an actual manifestation of the wrathful form of Guru Rinpoche, Dorje Drolö (rDo rje gro lod). ${ }^{27}$ Thus, the three principal lamas who have been identified in their own life-times as revealers in this rebirth lineage, that is, Düdül Dorje, Dudjom Lingpa, and Dudjom Rinpoche, all had important revelations connected with both Vajrakīlaya and Dorje Drolö, and the two Dudjom lamas have been consistently identified as Dorje Drolö manifestations. Indeed, this is one of the main explanations used for Dudjom Lingpa's appearance in an apparently rather violent guise. There is no doubt that the symbolism of Dudjom Lingpa as a wrathful deity personified is central to Dudjom Rinpoche's inclusion of the account of Dudjom Lingpa's wild childhood within his religious history of the Dudjom Vajrakīlaya practice. In fact, the specific Dorje Drolö symbolism is embodied in one now rather dominant artistic representation of Dudjom Lingpa. 


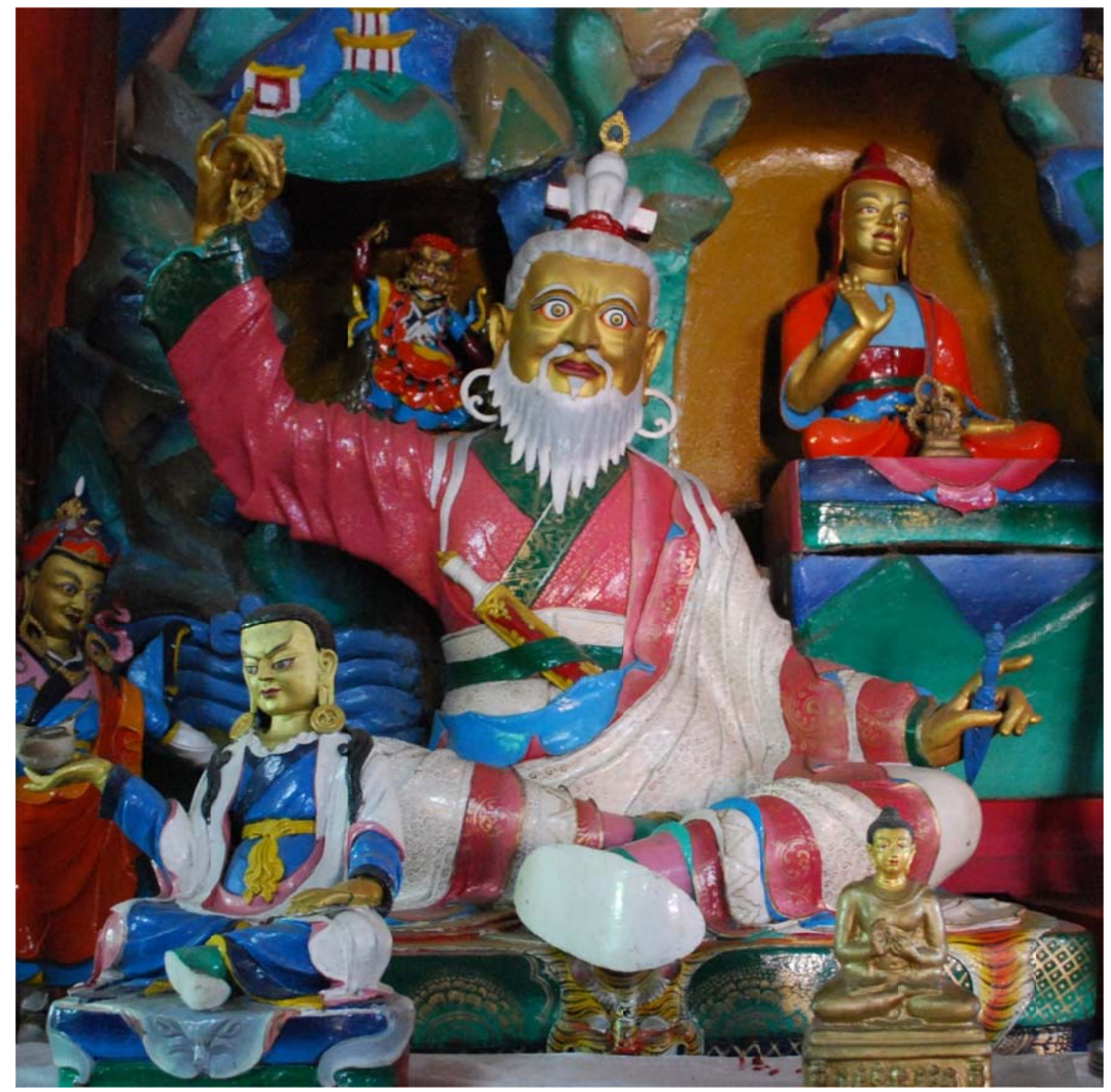

Figure 3. Dudjom Lingpa statue in the Zangdok Palri Monastery, Kalimpong.

Photograph by Cathy Cantwell (2009).

He is invariably depicted holding a vajra in his right hand and a phur bu in his left, taking up the characteristic pose of the Dudjom tradition Dorje Drolö, with both arms fully stretched out. It is rather harder to equate aspects of Dudjom Rinpoche's everyday persona with Dorje Drolö, but a close identification with the deity was clearly an important part of his spiritual experience. He recounts that he received his Dorje Drolö revelation at the age of only thirteen, and again at age twenty-four, following which he kept it secret for many years. He gained great confidence in this revelation, while 
appearing outwardly merely to be practising Düdül Dorje and Dudjom Lingpa's Dorje Drolö manuals. $^{28}$

It seems that most of the figures included in the supplication to Dudjom Rinpoche's earlier incarnations are not part of a more widely identified series of births but rather illustrate the breadth of qualities considered to be embodied in Dudjom Rinpoche himself. The source for the list is said to be the revelation prophecies (associated with Dudjom Rinpoche) and the past masters' words (Dudjom Rinpoche 1979-1985, vol. A, 30; see note 12 above). A shorter version of the list, giving nine previous births, is found in Dudjom Lingpa's Autobiographies (Dudjom Lingpa 2011, 7, 206-207), and he also mentions (137) being born as ten revealers following Khyeuchung. However, the list associated with Dudjom Rinpoche includes Smṛtijñānakīrti and Rongzom Chökyi Zangpo (Rong zom chos kyi bzang po, 10121088), who were great scholars, but not considered tertön (gter ston, 'treasure revealers') as well as important religious figures of other schools, such as Lingje Repa (Gling rje ras pa, 1128-1188), who was a student of Pakmo Drupa (Phag mo gru pa, 1110-1170) and an early Drukpa ('Brug pa) lineage master (Martin 2008; Townsend 2010).

It is clear, however, that the additional figures were not simply added by Dudjom Rinpoche. A much longer list of the previous incarnations of Düdül Dorje is given in a namthar (rnam thar, 'hagiography') compiled by Takrepa Künzang Pema Loden (Stag ras pa kun bzang padma blo ldan, 1997), apparently a direct student of Düdül Dorje's. The account reflects material in a series of revelatory supplications produced by Düdül Dorje in response to requests from various students. ${ }^{29}$ The large number of names linked with Düdül Dorje includes most of those on Dudjom Rinpoche’s list up to Düdül Dorje himself_-including Smṛtijñānakīrti, Lingje Repa, and 
Phakpa ('Phags pa) — but appears to omit Saraha, Rong zom, and the founder of Katok, Katok Dampa Deshek (Kah thog Dam pa bde gshegs, 1122-1192). Dampa Deshek is in Dudjom Lingpa's list, but Saraha and Rong zom are not. ${ }^{30}$

Above all, the associations between Dudjom Rinpoche and these illustrious masters of the past would suggest a range of qualities, encompassing scholarly and meditative accomplishment, and political achievement, as well as indicating an ecumenical flavour to the series of rebirths. But apart from Khyeuchung, the predecessor of both Dudjoms who was singled out by Dudjom Lingpa, and whose revelations have the most obvious and direct linkage with Dudjom Lingpa, was the $17^{\text {th }}-$ century lama, Düdül Dorje (bDud 'dul rdo rje, 1615-1672). ${ }^{31}$ There is no doubt that Dudjom Rinpoche experienced a special affiliation with Düdül Dorje and his revelation cycles (see note 12). Dudjom Rinpoche re-presented and commentated on several of Düdül Dorje's cycles, and he established the transmissions and regular practice of them by the next generation of his students. He also played a key role in the preservation and reprinting of Düdül Dorje's works in exile, a task made particularly urgent by the loss of texts following the Chinese invasion and Cultural Revolution.

Düdül Dorje was from the Derge (sDe dge) area in Eastern Tibet, and he became an important lineage lama for the Katok tradition. His student, another highly productive revealer, Longsel Nyingpo (Klong gsal snying po, 1625-1692), became the Head Lama of the old Nyingma establishment of Katok Monastery and conducted major renovations there. ${ }^{32}$ Longsel Nyingpo's son, Sönam Deutsen (bSod nams lde’u btsan, 1679-1723), who became the teacher of the famous Katok Rinzin Tsewang Norbu (Kah thog rig 'dzin Tshe dbang nor bu, 1698-1755), is considered the next following Düdül Dorje in the series of Dudjom Rinpoche's former births. However, Düdül Dorje himself spent little time at Katok. For most of his career, he travelled in the Powo (sPo bo) or 
Puwo (sPu bo) region, where he brought forth his major revelation cycles, and he is also famous for opening up the sacred "hidden land" of Pemakö (Padma bkod), where Dudjom Rinpoche was born and raised. He even produced spiritually inspired revelations from afar. He apparently miraculously visited the holy site of Samye (bSam yas), the first monastery in Tibet, to collect Treasure Revelations, and when the temple's guardian deity, Pehar Gyalpo (Pe har rgyal po), challenged him, he retorted that the items had been given to him by Guru Rinpoche. ${ }^{33}$

Dudjom Rinpoche incorporates the verses and imagery of Düdül Dorje's Lama Heart Practice into his own Guru Rinpoche Lama Heart Accomplishment Practice. This practice combines the revelations of seven masters, starting with Guru Chökyi Wangchuk (Gu ru Chos kyi dbang phyug, 1212-1270)'s Lama Sangdü (Bla ma gsang 'dus), and culminating with his own practice as the seventh, while Düdül Dorje's Complete Embodiment of the Enlightened Intention (Dgongs pa yongs'dus) is the sixth. In fact, a set of initiation cards (tsak li) designed for Düdül Dorje's cycle and apparently printed in Taiwan, continues to be used by the current Dudjom tradition for empowerment into Dudjom Rinpoche's Lama Heart Accomplishment Practice. This practice underlines Dudjom Rinpoche's work in preserving the early revelations, while it simultaneously emphasises within the transmission the specific identification between himself and Düdül Dorje, in this case missing out Dudjom Lingpa altogether.

Perhaps the most interesting example of Dudjom Rinpoche's assimilation of Düdül Dorje's heritage is his Meteoric Iron Razor (Gnam lcags spu gri). As noted above, this is Dudjom Rinpoche's work on Dudjom Lingpa's largest Vajrakīlaya cycle, reproducing much of the earlier root revelation verses, yet also adding to them. ${ }^{34}$ In this case, the tradition generally seems to understate Dudjom Rinpoche's contribution. His Meteoric Iron Razor is often identified simply as Dudjom Rinpoche's compilation of 
Dudjom Lingpa's revelation, yet it is much more than this. Even the name, Meteoric Iron Razor, is not given as a title in Dudjom Lingpa's works but derives primarily from a label given to Düdül Dorje's Vajrakīlaya revelation early in its transmission. Dudjom Rinpoche comprehensively re-packages and extends Dudjom Lingpa's revelation, creating new liturgies and commentarial texts. Dudjom Lingpa's revelation was in clear continuity with Düdül Dorje's, and the works of all three lamas demonstrate a common identity. But Dudjom Lingpa's revelation departs in a number of respects from Düdül Dorje's. One significant aspect of Dudjom Rinpoche's contribution is to bring back and re-integrate some of Düdül Dorje's material which is not found in Dudjom Lingpa. For instance, the short Tsok (tshogs, 'feast practice') of the Meteoric Iron Razor cycle, which is widely used in the Dudjom tradition, in fact owes more to Düdül Dorje than to Dudjom Lingpa, while various lines or passages in the main Ritual Manual (las byang) of the Meteoric Iron Razor are Düdül Dorje's.

To conclude, a lama has the duty to propagate the heritage of his previous incarnations, but also the duty to correct, clarify, and expand on them where necessary. In some cases, editing and re-writing of the earlier texts may not be clearly distinguished from the original work. Lopon P. Ogyan Tanzin made the point that Dudjom Rinpoche's reworking of texts he wrote in his previous lives is analogous to someone re-visiting their own work after some years. They would notice errors and want to correct it. In short, the identification between the individuals may to some extent undermine the general rule that the sacred words of a terma (gter ma) revelation are not to be tampered with. The editing, re-ordering, and re-framing of earlier tantric works is an important part of the role of scholar lamas, but perhaps liberties can be more easily taken when the lamas are linked in a line of rebirths. 
I would like to acknowledge the support of the Arts and Humanities Research Council of the UK, who funded the research project on which this paper is based (AH/H039805/1). I would also like to thank Lopon P. Ogyan Tanzin Rinpoche, who acted as the research project's lama consultant, and with whom I have discussed the materials in this paper at length. I am of course responsible for any errors. An earlier version of the paper was originally presented at the conference, Beyond Biography: New Perspectives on Tibetan Life-Writing, Wolfson College, University of Oxford, September 2012.

\section{References}

Dudjom Lingpa. 1979. Khros ma'i sgrub skor [The Khros ma Practice Cycle]. Kalimpong: Mani Dorji. (TBRC W1KG9609).

Dudjom Lingpa. 1994. Buddhahood Without Meditation: A Visionary Account known as, Refining Apparent Phenomena (Nang jang). Junction City, CA: Padma Publishing.

Dudjom Lingpa. 2004. Gter chos/ bdud 'joms gling pa; Sprul pa'i gter chen bdud 'joms gling pa'i zab gter gsang ba'i chos sde [Secret Profound Dharma Treasures of the Great Emanated Revealer, Dudjom Lingpa], 21 volumes. Thimphu Bhutan: Lama Kuenzang Wangdue. (TBRC W28732). [Note that a version of this Collected Works in dbu med script had been published in 1978 in Kalimpong (TBRC W21728); the relevant passages cited have also been checked in this earlier version].

Dudjom Lingpa, Traktung. 2011. A Clear Mirror: The Visionary Autobiography of a Tibetan Master, translated by Chönyi Dolma, A. Holland. Hong Kong: Ranjung Yeshe. [The Tibetan version is found in Dudjom Lingpa 2004, vol. Dza]

Dudjom Rinpoche. 1979-1985. The Collected Writings and Revelations of H. H. bDud’joms Rin-po-che 'Jigs bral ye shes rdo rje, 25 volumes. Kalimpong: Dupjung Lama. (TBRC W20869)

Dudjom Rinpoche, Jikdrel Yeshe Dorje. 1991. The Nyingma School of Tibetan Buddhism: Its Fundamentals and History, 2 volumes. Boston: Wisdom Publications.

Düdül Dorje. 1997 Spo bo gter ston bdud 'dul rdo rje'i zab gter gsung 'bum [Collected Profound Treasures of the Spo bo Revealer, Düdül Dorje], 12 volumes. Darjeeling: Kargyud Sungrab Nyamso Khang. (TBRC W22123). 
Dzongsar Khyentse Rinpoche. 2018. "Vajrayana Buddhism in the Modern World.

Berlin Talk." Rigpa Video on youtube, online. Accessed March 2, 2018.

https://www.youtube.com/watch?v=NWcjJzmOKQk

Ekvall, R. B. 1964. "Peace and War Among the Tibetan Nomads." Tibetan Symposium, American Anthropologist New Series 66(5): 1119-1148.

Garry, R. 2007. "Dudjom Lingpa.” In The Treasury of Lives, online. Accessed February 2, 2018. http://www.treasuryoflives.org/biographies/view/Dudjom-Lingpa/9688

Gayley, H. 2010. “The Scions of Dudjom Lingpa.” In Tibetan Buddhist Resource Center, online. Accessed April 21, 2012. http://about.tbrc.org/the-scions-ofDudjom-lingpa/

Gayley, H. 2011. “Who's Who in the Dudjom Lineage?” In Tibetan Buddhist Resource Center, online. Accessed April 21, 2012 http://about.tbrc.org/whos-who-in-theDudjom-lineage/

'Jam dbyangs mkhyen brtse chos kyi blo gros. 2012. 'Jam dbyangs chos kyi blo gros ris med bstan pa'i rgyal mtshan dpal bzang po'i gsung 'bum [Collected Works of 'Jam dbyangs chos kyi blo gros, Glorious and Good Victory Banner of the nonsectarian Dispensation], 12 volumes. Bir, H.P.: Khyentse Labrang. (TBRC W1KG12986).

Mandelbaum, A. 2007. "Khyeuchung Lotsāwa.” In The Treasury of Lives, online. Accessed March 8, 2018. https://treasuryoflives.org/biographies/view/Khyeuchung-Lotsawa/13077

Martin, D. 2008. “Lingrepa Pema Dorje.” In The Treasury of Lives, online. Accessed March 9, 2018. https://treasuryoflives.org/biographies/view/Lingrepa-PemaDorje/11877

Mkha' khyab rdo rje (15 ${ }^{\text {th }}$ Karma pa). 1993/1994. “Gter gsar rdo rje phur pa yang gsang bcud dril gyi cha lag tshe sgrub 'chi med srog thig gi rtsa ba'i dbang bskur rgyas par phye ba 'chi med nor bu pad ma'i phreng ba" [Extensive Main Empowerment for the Creative Seed of Immortality, the Longevity Practice Auxiliary for the New Treasure Ultra Secret Quintessence Vajrakīlaya]. In Rgyal dbang mkha' khyab rdo rje'i bka' 'bum [Victorious Mkha' khyab rdo rje's Collected Works], vol. Ga (3), 259-458. Delhi: Majnu-Ka-Tilla, Konchhog Lhadrepa. (TBRC W22081-0361) 
Mkhan po padma rig 'dzin. 2004. Skyabs rje bdud 'joms sku gong 'og rnam thar

[Hagiographic Account of the Former and Latter Refuge Lord Dudjom], edited by H.H. the Jadral Sangye Dorje Rinpoche [n.p.].

Namgyal Tantric College. 2008-2018. His Holiness the Sixth Dalai Lama Tsangyang Gyatso, online. Accessed February 2, 2018.

https://www.namgyalmonastery.org/the-dalai-lamas/his-holiness-the-sixth-dalailama-tsangyang-gyatso/

Rigpa Shedra. "Humkara” (data entry), online. Accessed February 2, 2018.

http://www.rigpawiki.org/index.php?title=Humkara

Ronis, J. 2006. "Bdud dul rdo rje (1615-1672) and Rnying ma Adaptations to the Era of the Fifth Dalai Lama." In Power, Politics and the Reinvention of Tradition in Seventeenth and Eighteenth Century Tibet: Proceedings of the International Association for Tibetan Studies, Xth Seminar, Oxford University, 2003, edited by K.R. Schaeffer and B.J. Cuevas, 171-186. Leiden: Brill.

Ronis, J. 2009. “Celibacy, Revelations, and Reincarnated Lamas: Contestation and Synthesis in the Growth of Monasticism at Katok Monastery from the 17th through 19th Centuries." Ph.D. diss., University of Virginia.

Shenpen Dawa Rinpoche. 1991. "Foreword." In The Nyingma School of Tibetan Buddhism, written by Dudjom Rinpoche, translated by Gyurme Dorje and M. Kapstein, vol. one, xxv-xxviii. Boston: Wisdom Publications. [Reprinted online in slightly edited form: http://www.tersar.org/teachers-2/h-h-Dudjom-rinpoche/] Townsend, D. 2010. “Pakpa Lodro Gyeltsen.” In The Treasury of Lives, online.

Accessed March 9, 2018. https://treasuryoflives.org/biographies/view/PakpaLodro-Gyeltsen/2051

Tsewang Dongyal, Khenpo. 2003. Bdud 'joms 'jigs bral ye shes rdo rje'i rnam thar ye shes rdo rje'i 'od zer [Hagiographic Account of Dudjom 'Jigs bral ye shes rdo rje, Primordial Wisdom Vajra Light Rays]. Sarnath: Pema Samye Chokhor Ling Nyingmapa Buddhist Monastery. [For an English version, see Khenpo Tsewang Dongyal 2008]

Tsewang Dongyal, Khenpo. 2008. Light of Fearless Indestructible Wisdom: The Life and Legacy of H.H. Dudjom Rinpoche. Ithaca, N.Y.: Snow Lion Publications.

Stag ras pa kun bzang padma blo ldan. 1997. "Bdud 'dul rdo rje'i rnam thar gter 'byung mdor bsdus pa dad pa'i mchod stong" [Concise Hagiographic Account of the Origins of Düdül Dorje's Revelations, A Thousand-fold Offering of Faith]. In 
Spo bo gter ston bdud 'dul rdo rje'i zab gter gsung 'bum [Collected Profound

Treasures of the Spo bo Revealer, Düdül Dorje], written by Düdül Dorje, vol.

Tha, 1-53. Darjeeling: Kargyud Sungrab Nyamso Khang. (TBRC W22123)

Wickham-Smith, S. 2012. “The Sixth Dalai Lama, Tsangyang Gyatso.” In The Treasury of Lives, online. Accessed February 2, 2018.

http://www.treasuryoflives.org/biographies/view/Sixth-Dalai-Lama-TsangyangGyatso/5871

Yeshe Thaye. [n.d.] A Short Life Story of His Holiness Kyabje Chadral Sangye Dorje

Rinpoche. Dudjom Buddhist International, online. Accessed February 2, 2018. http://Dudjominternational.org/?page id=276

Yeshe Thaye. 1999. Updated 2015 A Short Life Story of His Holiness Kyabje Dudjom Rinpoche (1904-1987). Dudjom Buddhist International, online. Accessed

February 2, 2018. http://Dudjominternational.org/?page $\mathrm{id}=268$

1. Note that in this article, I have referenced several non-academic internet sources on the lamas discussed, to draw attention to stories told publicly about them. Where available, dated entries with acknowledged authors have been preferred. The Rigpa Shedra sources may change, yet the general depictions I am highlighting here are unlikely to change substantially.

2. See Dudjom Lingpa (2011, 291-297) for a useful summary by Chönyi Drolma of Dudjom Lingpa's descendants and students. See also Holly Gayley (2010; 2011).

3. ha cang rgod bag che bas rtag par bsrung dgos pa byung / dgung lo bcu pa'i thog zhang pos bu zlar khrid nas de'i khyim du re zhig bzhugs dgos pa byung ba'i tshe phyugs 'tsho ba sogs las ka sna tshogs bkol ba na/ skyer mdas khro zangs lcags yob mkhar gzhong thams cad khrol mar phug cing bcag grum sha stag byas pas/zhang po dang sru mo rnams kyis na re / bu 'di the'u rang gis rgyud brlam pa yin 'dug pas yi ge zhig bslab na bandhe re 'ong / de min mi skya byas na mi phung rang brlag byed mkhan zhig 'ong nges red zer nas chos slob par gtong rtsis byas/(Dudjom Rinpoche 1979-1985, vol. Tha, 63-64; Mkhan po padma rig 'dzin 2004, 3-4 repeats the passage in the same words).

4. Dudjom Lingpa $(2011,28)$; the equivalent passage is in Dudjom Lingpa (2004, vol. Dza, 3940).

5. This is succinctly expressed in the short single verse version of the Supplication to his series of rebirths: "Now, Pema Jungney's Regent" (da lta pad 'byung rgyal tshab, Dudjom Rinpoche 1979-1985, vol. A, 31). 
6. P. Ogyan Tanzin, personal communication, 2012. Jamyang Khyentse Chökyi Lödro (2012, vol. Ga, 527-528) wrote a supplication for the long life (zhabs brtan du gsol ba) of Dudjom Rinpoche, entitled, “The Drumbeat of Immortality” ('chi med rnga sgra), which is dated the Earth Ox (sa glang) year (1949). Of course, such supplications for lamas typically express exuberant praises, but the first verse speaks of his emanations having one and the same primordial wisdom as Guru Rinpoche and Drokben Lotsāwa (rgyan rje dang 'brog ban lo tsā yi / lye shes gcig nyid du mar 'char ba'i 'phrul), and one of the later verses describes him as "the great regent who is the messenger of Pema" (padma'i pho nya rgyal tshab chen po).

7. A prophecy of Ogyan Dechen Lingpa (O rgyan bde chen gling pa)'s is repeatedly cited as indicating Dudjom Rinpoche's main contribution: gter gsar 'byin nam gter rnying bstan pa skyong " $(\mathrm{He})$ will either bring forth new revelations or protect the teachings of the old revelations" (Khenpo Tsewang Dongyal 2003, 25, my translation; the equivalent passage is in 2008, 65). Dudjom Rinpoche is said to have on many occasions refrained from decoding revelations due to his decision to focus on the latter role.

8. gong ma'i skye sprul gyi mtshan tsam 'chang ba ma yin par / de rnams kyi thugs rgyud la bzhugs pa 'i mkhyen gnyis lung rtogs kyi yon tan rang chas su yod pa'i dan rtags su / phyi'i gsan sbyangs kyi tshegs la ma ltos par / shes bya'i gnas kun gsan pa tsam gyis de dag gi don khongs su chud (Khenpo Tsewang Dongyal 2003, 57; the equivalent passage is in 2008,94$)$.

9. Khenpo Tsewang Dongyal writes: "From that time, there was no need for (Dudjom Rinpoche) to weary himself with persistent efforts, absorbing and recollecting (the practice), or to have the hardships of months and years of retreat. (His) mind became (self-)assured and relaxed, vast and spacious. (Dudjom Rinpoche) would say that (this was due to) the inherent spiritual power (of Zilnön's) transmission of the ultimate mind lineage." (de nas bzung 'ju dran u tshugs kyi ngal ba dang / lo 'tshams zla mtshams sogs sdug yus kyi grangs bgrangs ma dgos par sems bde shig ge dang yangs khrol le byung ba don brgyud kyi dgongs pa 'phos pa'i mthu yin pa dra gsungs, Khenpo Tsewang Dongyal 2003, 50-51; my translation; the equivalent passage is in 2008, 89-90).

10. This account was related to P. Ogyan Tanzin by residents of Dudjom Rinpoche's home area in Pemako who had themselves witnessed the event. In part, the lama's apparent lack of objection may reflect recognition of his wife's rights to the movable property (mo nor), yet it seems that the local community was astonished at his willingness to acquiesce to its complete removal. The story does not imply that he was unaffected by the separation; merely that he was not attached to the possessions and also preferred to avoid any dispute. 
11. Lama Kunzang Dorjee, personal communication, December 2013. The story is based on an account by his father, Pema Longdröl (Padma Klong grol), who acted as Dudjom Rinpoche's attendant for many years. Apparently, this happened in the period soon after Lama Pema Longdröl had joined Dudjom Rinpoche's circle, and Lama Pema Longdröl's terror at the time was in future years recalled with amusement by the two lamas.

12. In an edited edition of Dudjom Lingpa's account of his visions, Dudjom Rinpoche speaks of presuming himself to be an apparitional display of a (re)birth of the great Heruka Vidyādhara (i.e. Dudjom Lingpa1994, 178-179: khrag 'thung rig 'dzin chen po'i skye ba'i sgyu gar du rlom pa 'jigs bral ye shes rdo rje ste). He composed a supplication for his students to recite, made up of a number of verses, each to one of the identified persons in the series of rebirths including Dudjom Lingpa and himself (skyes rabs gsol 'debs muktika 'i do shal, Dudjom Rinpoche 1979-1985, vol. A, 25-31; see also below). He made no claim that these identifications came from his own visions; he says clearly in the colophon to the supplication that it was "based on the sources of the revelation prophecies and the past Vidyādhara masters' words" (gter lung rnams dang rig 'dzin gong ma 'i gsung la khungs su byas te), which primarily would appear to point to Dudul Dorje's and Dudjom Lingpa's writings. The supplication is recited regularly in Dudjom tradition monasteries and centres. In the context of writing the colophon to an empowerment text for Dudul Dorje's Lama Accomplishment practice, the Complete Embodiment of the Enlightened Intention (Dgongs pa yongs 'dus), Dudjom Rinpoche recounts how "the lotus of my mind was opened" when his lama Garwang Sangye Dorje Düpatsel (Gar dbang sangs rgyas rdo rje 'dus pa rtsal) initiated him into the cycle, so that, "the Greatly Blissful Padmasambhava consecrated me within the series of the garland of the lives of 'Brog ban lo tsā ba" (khyab bdag bla ma rdo rje sems dpa'i ngo bor bzhugs pa gar dbang sangs rgyas rdo rje 'dus pa rtsal gyi zhal snga nas chos skor yongs rdzogs kyi smin grol bdud rtsi'i dga' ston skal pa bzang po'i dpyid du stsal ba'i tshe..... yid kyi padmo kha phyes pa la brten nas / bde ba chen po padma sambha was 'brog ban lo tsā'i skyes pa rabs kyi phreng ba'i gral du byin gyis brlabs pa, Dudjom Rinpoche 1979-1985, vol. Ja, 536-537).

13. See the Rigpa Shedra data entry.

14. Dudjom Lingpa 2011, p. 83. The Tibetan of the passage: nga'i dgongs rgyud 'pho ba dang gdams ngag chu klung bzhin du brdol 'ong gsungs pas rmi lam dbyings su sad (Dudjom Lingpa 2004, vol. Dza, 108).

15. See, for instance, Dudjom Lingpa (2011, 7, 9, 13 , 15, 27, 33, 79, 80, 94-95, 98, 128, 137 , $165,190,206,210-211,240,245)$. There is also an interesting account in the Autobiography of an encounter with the tantric deity, Vajrapāṇi, who identifies Dudjom 
Lingpa as his own wisdom mind emanation (khyod kyang nga'i thugs kyi sprul pa yin, Dudjom Lingpa 2004, vol. Dza, 175; Dudjom Lingpa 2011, 130), although Dudjom Lingpa was initially terrified by the deity's appearance (mjal ba'i tshe bdag shin tu bred cing dngangs nas, Dudjom Lingpa 2004, vol. Dza, 174). It seems that the identity of an enlightened being and his emanation will not always be obvious even to the emanated individual.

16. Dudjom Lingpa (2011, 7, 206; the equivalent passages are in Dudjom Lingpa (2004, vol. Dza, 11, 274, which has the very explicit claim: nga ni hüm chen kā ra lags).

17. nga ni rig 'dzin hüm chen kā ra zhes bya ba yin / khyod ni nga'i phrin las kyi sprul pa yin (Dudjom Lingpa 2004, vol. Dza, 134; Dudjom Lingpa 2011, 102).

18. nyid rigs bdag gter chen chos kyi rgyal po'i skye srid 'khrul pa'i dri ma dang bral ba lags na sku lus kyi bkod pa na bsgres gzhon go brjes pa tsam las don brgyud kyi dgongs pa la 'pho 'gyur bri gang mi mnga' ba ni zhu ma dgos (Khenpo Tsewang Dongyal 2003, 47; the equivalent passage is in 2008,86 ).

19. de lta'i nyams rtogs kyi yon tan rnams sbrul shun brje ba ltar / sku skye re re'i phung po'i lhan du dor ba ma yin par (Khenpo Tsewang Dongyal 2003, 57, my translation; the equivalent passage is in 2008,95$)$.

20. P. Ogyan Tanzin, personal communication. I am uncertain how far-if at all—Dudjom Lingpa actually acted as a political/social mediator or adjudicator of disputes. There is scant information in his Autobiographies about the "worldly" aspects of his life, since the narratives deal almost exclusively with his visionary encounters and spiritual activities. Ekvall $(1964,1141)$, basing himself primarily on his fieldwork in Amdo in the early $20^{\text {th }}$ century, writes that lamas and high ecclesiastical dignitaries were preferred as mediators, and that all mediators needed eloquence, as well as status and reputation (kha ngo can). Perhaps Dudjom Lingpa's image as an imposing character might not seem ideal for a successful persuasive mediator, especially since he does not appear to have been backed by the large monastic authorities of the region. Yet his reputation as a saintly and powerful lama was well-established by his later years, and he might have been sought out. At the very least, it would seem that his commanding presence provided some support and defence for his own community and followers.

21. Politically speaking, Dudjom Rinpoche was patronised in his early career by the Powo authorities; his paternal grandfather, Kanam Depa (Ka gnam sde pa), was the ruler of Powo, which included the Pemako area. After Kanam Depa was deposed, the Tibetan State authorities appear to have felt threatened by everyone in any way associated with the former ruler, and Dudjom Rinpoche had to tread carefully in his attempts to establish his 
religious centres. Later, of course, the political powerlessness of exile might have posed considerable further restraint, although the Bhutanese State, as well as numerous devoted individual sponsors, did much to support his work, and bolster his position with the Tibetan and Indian authorities.

22. gsang bdag dngos byon phug sprul 'gyur med nges don dbang po'i mdun nas / rin chen gter gyi mdzod / sgrub thabs 'dod 'jo bum bzang/smin gling gter gsar skor / rje mkhyen brtse rin po che'i bka' babs bdun gyi chos skor / bdud 'joms gter gsar skor bcas kyi smin grol rgyab brten yongs rdzogs / mdzod bdun gtso bor gyur pa 'i klong chen pa'i gsungs dpe lung gi rgyun bzhugs so cog gso rig rgyud bzhi rtsa 'grel dpal sprul gsungs 'bum sogs lung khrid rigs shin tu mang ba (Khenpo Tsewang Dongyal 2003, 46; see the equivalent list in 2008, 86).

23. Gyurme Ngedön Wangpo is mentioned as the chief of the presiding lamas at Dudjom Rinpoche's official installation as a young child as Dudjom Lingpa's rebirth (mchog sprul gang gi zhabs sen padma'i 'dab stong spyi bo bde chen 'khor lo'i rgyan du bkod nas / grub pa'i dbang phyug phug sprul 'gyur med nges don dbang po dang / gling bla ma o rgyan chos 'byor rgya mtsho'i dbus slob tshogs dag gis theg dgu'i chos kyi senge'i khri 'phang du bdud 'joms gong ma 'i sprul skur mnga' gsol to, Khenpo Tsewang Dongyal 2003, 35; see the equivalent passage in 2008, 75). The other lama mentioned here, Ogyan Chöjor Gyatso (O rgyan chos 'byor rgya mtsho), also bestowed many teachings upon Dudjom Rinpoche in addition to the Dudjom Lingpa heritage and instructed him to complete the Longchen Nyingtik (Klong chen snying thig) tantric Foundation Practices before he performed the Dudjom Foundation Practices (Khenpo Tsewang Dongyal 2003, $44-45 ; 2008,85)$.

24. This destiny of conduct like a child (cha lugs ma nges byis spyod shes rab can) is indicated in the prophecy of Ogyan Dechen Lingpa's which is considered to be associated with Dudjom Rinpoche (Khenpo Tsewang Dongyal 2003, 25; the equivalent passage is in 2008, 65; see also note 7 above). It was interpreted by P. Ogyan Tanzin to suggest that Dudjom Rinpoche would be as amenable and innocent as a young child, playful, non-judgmental, and always interested in others.

25. In the case of the Treasure revealer, Zilnön Namkhe Dorje, he is seen rather unusually as an emanation of two of Guru Rinpoche's students, Vairocana and Nanam Dorje Dudjom (Sna nam rdo rje bdud 'joms). The $15^{\text {th }}$ Karmapa's account of the transmission of his Creative Seed of Immortality ('Chi med srog thig) revelation relates how the Guru Padma entrusted the pair with the teaching and made a prophecy that they would arise in a single primordial wisdom manifestation, and this constituted the specially authorised predicted transmission. 
Then he put the volume onto their heads, consecrating them, and they, "made a really farreaching aspiration, with a single-pointed longing to effect the benefit of future beings in later times. This was the transmission of the empowered aspiration" (ma hä gu ru o rgyan rdo rje 'chang chen pos / zab chos kyi glegs bam bai ro dang / bdud 'joms zung gi spyi bor bzhag cing dgongs brgyud kyi byin rlabs 'pho ba'i dbang bskur / chos kyi bdag po zung gis kyang ma 'ongs phyi ma'i dus su 'gro don spyod pa'i thugs 'dun rtse gcig pas smon lam rgya chen po btab pa ni smon lam dbang bskur gyi brgyud pa, Karma pa 15, 1993/1994, vol. Ga, 317-318).

26. rdzu 'phrul gyis nam mkha'i bya rnams kyang lta stangs dang sdigs mdzub tsam gyis 'gugs par nus (Dudjom Rinpoche 1979-1985, vol. Tha, 61).

27. "Herder practitioner Khyeuchung, who is actually Drolö in person" (gro lod mngon gyur 'brog ban khye'u chung, Dudjom Lingpa 1979, vol. 1, 77-78). Dudjom Lingpa's Autobiographies also frequently proclaim his special connection with Dorje Drolö and with Vajrakīlaya (Dudjom Lingpa 2011, 10, 23, 35, 64, 209, 221, 280). See in particular, Guru Rinpoche's order for him to be born in the form of Dorje Drolö: de phyir rig 'dzin rgyal po khyod/ rdo rje khro lod skur bzhengs te (Dudjom Lingpa 2004, vol. Dza, 15; Dudjom Lingpa 2011, 10); and the words of a primordial wisdom dẹkiniñ, declaring him to be Dorje Drolö: skye mchog rdo rje khro lod khyod (Dudjom Lingpa 2004, vol. Dza, 359; Dudjom Lingpa 2011, 280). On Dorje Drolö, see online: http://www.himalayanart.org/image.cfm/261.html (accessed March 8, 2018).

28. kho bo 'jigs bral ye shes rdo rjes rang lo bcu gsum par bdud 'dul gter byon gro lod kyi bsnyen sgrub phran bu bgyis pa'i skabs shig tshul 'di'i bskyed bzlas kyi rim pa blo ngor brdol thabs su shar zhing / phyis rang lo nyer bzhi par bdud 'joms gro lod kyi bsnyen bsgrub skabs shin tu gsal bar byung ba bcas/gzhan la bstan na rang srog 'chad pa'i tha tshig la 'jigs te gter kha gong ma gnyis kyi tshul du gsang bas nyams su len pa las / snyigs dus kyi bar chad rlung dmar lta bu'i khrod na tshe srog gi mar me 'di tsam gnas par gyur pa'ang gdams pa 'di kho na'i mthur nges pa rnyed la (Khenpo Tsewang Dongyal 2003, 168-169; the equivalent passage is in 2008, 180).

29. Supplications addressed to one's personal lama are an important feature of Tibetan tantric practice, frequently recited at the start of tantric rituals. They can include several page eulogies of different aspects of the lama's nature or activity, and also, four-line single verse supplications, which can be recited swiftly (or in some cases, repeatedly). The supplications to Dudul Dorje are collected under the title of The Supplication to Rigdzin Dudul Dorje's series of lives, A Garland of Pearls, of Clear and Profound Compassion, Rig 'dzin bdud 'dul rdo rje'i skye brgyud gsol 'debs mu tig phreng ba thugs rje zab gsal 
$m a$, in Dudul Dorje 1997, vol. Tha, 233-259. The first two of substantial length (234-237, 238-241) dwell on the different lives of the past, and like Dudjom Rinpoche's

Supplication, mention also the name of the buddha he will become in the future. They roughly follow a kind of chronological or logical order (beginning with the buddha/bodhisattva figures who emanate the series of masters), although it is not always clear throughout which words are names and which are epithets or descriptions, and they do not entirely repeat each other. The following supplications, which include one that focuses on Dudul Dorje's own life (a rnam thar gsol 'debs, or 'hagiographical supplication', 254-258), also give some mention of Dudul's identity with other great beings. Note that all these supplications are presented with the revelation punctuation (gter tsheg), and thus can be assumed to be revealed rather than composed.

30. I do not know what further sources Dudjom Rinpoche used to develop his specific and now standardised list.

31. See the Rigpa Shedra entry, online: http://www.rigpawiki.org/index.php?title=Rigdzin_Düddul_Dorje (accessed March 8, 2018)

32. Ronis $(2009,43-84)$ discusses Dudul Dorje's and Longsel Nyingpo's activities at Katok at length. See also Ronis (2006).

33. This and a number of similar accounts are given in Stag ras pa kun bzang padma blo ldan (1997, 35-36).

34. I am writing at length on these issues in my forthcoming book, Dudjom Rinpoche's Vajrakilaya Works: A Study in Authoring, Compiling and Editing Texts in the Tibetan Revelatory Tradition (Equinox). 